\title{
市場経済移行期のチェコにおける 銀行危機の展開*)
}

\author{
松澤祐介
}

\begin{abstract}
論文要旨： 移行期のチェコでは，銀行監督の不備，大銀行私有化の先送り，度重なる銀行救済とそ の安易なファイナンスの仕組等から，銀行部門で「モラル・八ザード」を発生する構造があり，移行 の「痛み」を緩和すべくこれが放置されたため，10年に渡る銀行危機の長期化を招いた。大銀行の私 有化, 銀行規制の EU 基準への調和等で状況は改善したが，膨大な不良債権という移行戦略の負の遺 産が依然として残されている。

[キーワード：チェコ，銀行危機，私有化，不良債権，モラル・八ザード］
\end{abstract}

\section{はじめに}

クラウス政権下のチェコの市場経済移行では, ミクロ面ではクーポン私有化が「成功裏」に達成 され，大銀行を頂点にした「金融資本主義」が形
成されたかの様相を呈していた。マクロ面でも， 安定化の尺度であるインフレ率, 財政赤字とも相 対的に低位で (表 1)，1995年には移行国初の OECD 加盟国となり，チェコの移行は「優等生」 として国際機関からも高い評価を得ていた。

表1 チェコ主要経済指標

\begin{tabular}{|c|c|c|c|c|c|c|c|c|c|c|c|}
\hline 年 & 1993 & 1994 & 1995 & 1996 & 1997 & 1998 & 1999 & 2000 & 2001 & 2002 & 2003 \\
\hline 実質経済成長率 & -3.2 & 4.8 & 5.9 & 4.3 & -0.8 & -1.0 & 0.5 & 3.3 & 3.1 & 2.0 & 2.9 \\
\hline $\begin{array}{l}\text { 物価上昇率 } \\
\text { (CPI 総合、年平均、\%) }\end{array}$ & 20.8 & 10.0 & 9.1 & 8.8 & 8.5 & 10.7 & 2.1 & 3.9 & 4. 7 & 1.8 & 0.1 \\
\hline $\begin{array}{l}\text { 失業率 } \\
\text { (年末值、\%) }\end{array}$ & 3.5 & 3.2 & 2.9 & 3.5 & 5.2 & 7.5 & 9.4 & 8.8 & 8.9 & 9.8 & 10.3 \\
\hline $\begin{array}{l}\text { 政策金利 } \\
\left(\text { 年末值、\%) }{ }^{1)}\right.\end{array}$ & 8. 0 & 8.5 & 11.3 & 12.4 & 14. 75 & 9.50 & 5.25 & 5.25 & 4. 75 & 2.75 & 2.0 \\
\hline $\begin{array}{l}\text { 銀行貸出残高 } \\
(コ ル ナ \text { 建、年末值前年比、\%) }\end{array}$ & 14.7 & 14.5 & 7.9 & 10.8 & -2.9 & -9.1 & -6.6 & -7.7 & -27.7 & -17.9 & 0.3 \\
\hline 信用乗数 ${ }^{3)}$ & - & - & - & - & 4.0 & 3. 7 & 4.0 & 3.8 & 3.5 & 3.1 & 3.1 \\
\hline $\begin{array}{l}\text { 為替レート } \\
\text { (コルナ対 ECU・ユーロ、年末値) }\end{array}$ & 33.4 & 34.3 & 34.9 & 34.3 & 38.0 & 35.2 & 36.1 & 35.1 & 32.0 & 31.6 & 32.4 \\
\hline $\begin{array}{l}\text { 経常収支 } \\
\text { (対 GDP 比、\%) }\end{array}$ & 1.3 & -1.9 & -2.6 & -7.4 & -6.1 & -2.3 & -2.9 & -5.3 & -5.7 & -6.0 & -6.5 \\
\hline $\begin{array}{l}\text { 一般政保財政収支 } \\
\left(\text { 対 GDP 比、\% }{ }^{4)}\right.\end{array}$ & -0.4 & -1.3 & -1.2 & -1.8 & -2.1 & -4.5 & -3.7 & -4.0 & -5.5 & -3.9 & -5.1 \\
\hline
\end{tabular}

注）1）政策金利は1994年分までは公定歩合，1995年以降はレポ金利 (2週間物)。

2）対民間企業向け（非金融機関），整理銀行分を含む。2001年は整理銀行から整理機構への改組，02年は IPB の 不良債権の整理機構への移転の影響が大きい。

3）信用乗数=居住者向け貸出（コルナ建）/ベースマネー。

4）2003年分は速報值。整理機構の不良債権伿却分を含む。

出所 : 一般政府財政収支は，欧州委員会 Regular Report on Czech Republic's Progress towards Accession および Comprehensive Monitoring Report 各年版（2003年のみチェコ大蔵省）。 
しかし97年の通貨危機を契機に評価は一変し た。私有化をめぐる不透明さが暴露される一方， 「金融資本主義」はその実「国有」大銀行が，经下 の投資基金を通じて细国営大企業を保有・支配す る「擬似」的なそれに過ぎなかった（池本・松澤， 2004）。ここで銀行部門に注目寸ると，移行初期か ら不良債権比率が極めて高く（表4），90年代半ば に相次ぐ中小銀行破綻で銀行危機が顕現化する。 中小銀行部門の処理・安定化策，大銀行に対する 移行開始初期からの各種不良債権処理策にも拘ら ず，98年頃からは大銀行の経営危機が表面化して 2000 年にはその一角が破綻，2003年にも中小 2 行 が破綻して，チェコの銀行危機は実に10年に渡っ た。このような銀行部門の脆弱性はチェコ経済の アキレス腱とされ，EU 加盟交涉に際しても欧州 委員会から繰り返し改善を求められた。

2004年に EU 加盟を果たしたチェコには，近い 将来の通貨統合参加が義務付けられている。その 際，(1)財政収支，インフレ率等マクロ指標の「マ 一ストリヒト基準」に加え，(2)欧州中銀の金融政 策が十分波及しうるほど安定した銀行制度の確立 という課題に直面する。しかし前者については， 危機の長期化で増嵩した「整理銀行（Konsolidačni banka）」保有の不良債権等への財政負担が将来の 財政赤字拡大一の㲘念を残している。また, OECD
（2003）や中銀の銀行監督年報（2002年版）では, 銀行部門の現状に楽観的な判断を下しているが, 通貨統合までを視野に入れた場合，その安定性が 担保されているか，十分な検討の余地がある。

ところで，社会主義時代からの不良債権や移行 開始後の経営環境等を原因に，ポーランド，ハン ガリーをはじめ，他の移行経済諸国でも銀行危機 は発生した（Tang et al., 2000)。しかしチェコで はこれが長期化した点が特徴である。そこで本稿 は, チェコでの銀行危機の発生と長期化の原因を, 主として銀行部門で生じた特有の「モラル・ハザ ード」に求め，その状況が看過された背景，およ び，それが今日解決をみているかを判断すること を目的とする。

\section{1 チェコにおける銀行部門の発展}

まず，移行開始から90年代半ばまでの銀行部門 の発展を略述する。1990年の二層銀行制度導入で は, 中央銀行からコメルチニー銀行 (Komerčni banka，KB）が分離創設され，また社会主義時代か ら存在していた，対外取引専門の海外貿易銀行 (Československá obchodní banka, CSOB), 個人貯 蓄専門の貯蓄銀行（Česká sporitelna, CS) が90年 から普通銀行に転換し，投資ポス卜銀行 (Investiční a Poštovní banka，IPB. 90年設立の投資銀行と郵便

表2 銀行数 (上段) および資産規模（下段，\%) の推移

\begin{tabular}{|c|c|c|c|c|c|c|c|c|c|c|c|c|c|c|c|c|}
\hline 年 & 90 年初 & 90 & 91 & 92 & 93 & 94 & 95 & 96 & 97 & 98 & 99 & $\vdots$ & 2000 & 2001 & 2002 & 2003 \\
\hline \multirow[t]{2}{*}{ 大銀行 } & 5 & 5 & 5 & 5 & 4 & 4 & 4 & 4 & 4 & 4 & 4 & 大銀行 & 4 & 3 & 4 & 4 \\
\hline & - & - & - & - & - & 77.5 & 73.0 & 68.1 & 65.6 & 66.0 & 65.1 & & 61.5 & 63.8 & 62.2 & 62.1 \\
\hline \multirow[t]{4}{*}{ 中小銀行 } & 0 & 4 & 14 & 19 & 22 & 21 & 18 & 12 & 9 & 8 & 5 & 中銀行 & 11 & 10 & 9 & 10 \\
\hline & - & - & - & - & - & 9.7 & 9.1 & 6.2 & 4.7 & 3.6 & 1.6 & & 18.2 & 14.8 & 16.6 & 15.8 \\
\hline & & & & & & & & & & & & 銀行 & 8 & 8 & 9 & 6 \\
\hline & & & & & & & & & & & & & 2.6 & 2.3 & 3.4 & 2 \\
\hline \multirow[t]{2}{*}{ 外国銀行 } & 0 & 0 & 4 & 8 & 11 & 12 & 12 & 13 & 14 & 13 & 13 & & & & & \\
\hline & - & - & & & & 7.1 & 9.9 & 12.2 & 14.6 & 15.6 & 15.7 & & & & & \\
\hline 外国銀 & 0 & 0 & 0 & 3 & 7 & 8 & 10 & 9 & 9 & 10 & 10 & 外国銀 & 10 & 10 & 9 & 9 \\
\hline 行支店 & & & & & & 4.1 & 6.0 & 6.4 & 7.7 & 9.5 & 11.4 & 行支店 & 11.8 & 12.8 & 9.6 & 9.6 \\
\hline \multirow[t]{2}{*}{ 専門銀行 } & 0 & 0 & 0 & 1 & 5 & 7 & 9 & 9 & 9 & 9 & 9 & 住宅専 & 6 & 6 & 6 & 6 \\
\hline & & & & & & 1 & 2 & 3 & 4 & 5 & 6 & 阴銀行 & 5.2 & 6.3 & 8. 2 & 10.5 \\
\hline 銀行数計 & 5 & 9 & 23 & 36 & 49 & 52 & 53 & 47 & 45 & 44 & 41 & & 31 & 29 & 28 & 29 \\
\hline
\end{tabular}

注）1990年初を除き，年末値。整理銀行を含めない。当該年の中銀管理下行分を除くため，資産規模合計は $100 \%$ にな らない年がある。

出所 : チェコ中銀・銀行監督年報・各年版。 
表3 大銀行の主要株主構成（1997年初時点）

\begin{tabular}{lclclclc}
\hline KB & $(\%)$ & CS & $(\%)$ & IPB & $(\%)$ & CSOB & $(\%)$ \\
\hline 国有資産基金 & 49 & 国有資産基金 & 45 & 国有資産基金 & 32 & チェコ中銀 & 26 \\
Bank of NY & 10 & 地方自治体 & 15 & Bankovni Holding & 24 & スロバキア中銀 & 24 \\
RIF & 4 & Motoinvest & 15 & Vojansk.savby & 20 & 国有資産基金 & 20 \\
IPB & 4 & RIF & 1 & チェコ郵便 & 20 & 大蔵省 & 20 \\
CS & 2 & & & PIAS & & \\
\hline
\end{tabular}

出所 : Shütte (2000), p. 243.

銀行が93年に合併) を加えて，4大銀行が形成さ

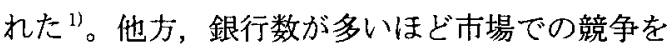
通じて効率的な金融システムが構築される，との 見方もあって民間銀行の新設も促され，90年段階 では最低資本金は5000万コルナと低く設定され， 銀行免許の認可基準も緩やか（Jonaš， 1998）で, 中小銀行数は急増した（表 2 ）。

ここで90年代半ばに出来上がった銀行システム とその問題点をみると，まず，大銀行は資産規模 で8割を占めて支配的となっていた（表2）。所有 構造では, 大銀行の私有化は部分的で, 引き続き 政府部門が大きな影響力を行使できる株数を有し ていた（表3）。他方「クーポン私有化」時に各大 銀行が積極的に設立した投資基金が，部分的に民 間に放出された銀行株を集め, 銀行間で相互に複 雑な持合い関係を形成した ${ }^{2)}$ 。

一方，新設の中小銀行は経営基盤が不安定であ った。資金調達面では，大銀行は社会主義時代の 支店網の利用などで預金を比較的容易に獲得でき たのに対して，中小銀行にはそれがなく，銀行間 市場に頼る（主として貸し手はCS）か, 高金利で 預金を獲得せざるを得なかった。他方, 貸出, 運 用面では，経営ノウハウやリスク管理に未熟なう え, 設立の経緯から関連企業もしくは株主といっ た「縁故者」向け融資の割合が高い場合もあった。 その上うな案件は, 緩い審査基準に加え, 当時ま だ銀行監督が不備だったことから見逃され，結果 として中小銀行の経営を不安定とする原因になっ た。

\section{2 銀行危機の展開とその対応・処理策}

\section{1 銀行危機の経過}

まず，危機の原因となる銀行部門の不良債権の 推移をみてみよう（表4）。チェコでは，社会主義 時代から企業の銀行依存度が高かったこと（融資
残高の対 GDP 比率は約70\%）もあり，移行開始 直後に, 社会主義時代の国有企業の在庫・運転資 金向けを中心に不良債権問題が露呈していた。次 節で述べる移行初期の不良債権処理スキーム，お よびその後の継続的な対策にも拘らず，90年代を 通じ，不良債権は全銀行貸出対比で $30 \%$ 前後之高 水準で推移し，対 GDP 比では90年代半ばに $25 \%$ を記録している（表4）。これは米国，日本それぞ れの各銀行危機ピーク期である1991年，2000年と 比較しても, 前者で $11.9 \%$, 後者で $12.3 \%$ であり (渡辺，2001)，チェコの抱えていた問題の大きさ が窥われる。

そうした中，銀行危機はまず新設の中小銀行か ら発生した。既に1992年頃から IMF 等が融資の質 を問題視していたが，94年頃から移行初期の貸出 が満期を迎えるに従い，これが回収不能となって 破綻が相次いだ（表5)。中小銀行の不良債権比率 は, 危機ピーク時の96年段階では $45 \%$ 超に達して いた。中小銀行には96年, 一連の危機対策が発動 された（2.2節参照）。しかし98年頃からは，4大 銀行のうち KB, CS, IPB の3行の経営危機が表面 化 (各行の不良債権比率は表 4参照) ${ }^{3)}$, IPB は2000 年に中銀の強制管理下に置かれ, CSOB に売却され て経営破綻した。さらに2003年には, 中堅銀行の ウニオン銀行, 小銀行のプルゼニュ銀行が相次い で破綻し，銀行危機は実に10年に渡り長期化した。

\section{2 銀行危機処理・安定化スキ一ム}

銀行危機に対して，3回の大規模なスキームに 加え, 継続的に各種の処理・安定化策が講じられ たが，以下これらを，不良債権処理およびセーフ ティーネット拡充の観点から整理する。

1）不良債権処理

不良債権処理には，大銀行および中小銀行向け それぞれにスキームが組まれた。大銀行では，先 
表4 銀行部門全体および大銀行各行の貸出に占める不良債権比率（\%)

\begin{tabular}{|c|c|c|c|c|c|c|c|c|c|c|}
\hline 年 & 1994 & 1995 & 1996 & 1997 & 1998 & 1999 & 2000 & 2001 & 2002 & 2003 \\
\hline $\begin{array}{l}\text { 銀行部門全体 } \\
\text { の不良債権 } \\
\text { うち }\end{array}$ & 36.0 & 34.2 & 32.9 & 33.4 & 26.5 & 32.2 & 29.8 & 21.5 & 16.9 & 11.1 \\
\hline 要注意先 & 7.8 & 6.6 & 6.3 & 6.1 & 6.0 & 10.1 & 9.9 & 8.0 & 8.5 & 6.2 \\
\hline 破綻懸念先 & 5.0 & 4. 4 & 3.2 & 2. 7 & 3.4 & 4. 3 & 6.4 & 3.4 & 3.3 & 1. 9 \\
\hline 実質破綻先 & 6.5 & 4. 1 & 4.1 & 3.4 & 3.6 & 4. 2 & 3.2 & 3.1 & 1.4 & 1.7 \\
\hline 破綻先 & 16.7 & 19.1 & 19.3 & 21.3 & 13.4 & 13.2 & 10.4 & 7.6 & 4.7 & 2.3 \\
\hline $\begin{array}{l}\text { 不良債権 } \\
\text { - 対 GDP 比 }\end{array}$ & 26.1 & 25.2 & 21.3 & 22.9 & 14.7 & 15.3 & 13.0 & 9.6 & 7.0 & 4.5 \\
\hline KBの不良債権 & 45.8 & 42.0 & 36.1 & 35.7 & 41.8 & 36.2 & 53.9 & 31.1 & 28.4 & 18.8 \\
\hline CS の不良債権 & 19.2 & 20.9 & 24.7 & 20.7 & 25.8 & 40.4 & 38.5 & 19.7 & 14.4 & 6.6 \\
\hline IPB の不良債権 & $\mathrm{n} / \mathrm{a}$ & $\mathrm{n} / \mathrm{a}$ & $\mathrm{n} / \mathrm{a}$ & 23.8 & 24.7 & $\mathrm{n} / \mathrm{a}$ & - & - & - & - \\
\hline
\end{tabular}

注）1）年末值。整理銀行分，業務停止行分は除く。

2）不良債権区分表

\begin{tabular}{|l|l|l|c|}
\hline & 支払い遅延 & \multicolumn{1}{|c|}{ 支払い可能性 } & 引当 $(\%)$ \\
\hline 要注意 & $30-90$ 日 & 期待される & 5 \\
破綻懸念先 & $90-180$ 日 & 部分的に期待される & 20 \\
実質破綻先 & $180-360$ 日 & 全般的にほほ不可能 & 50 \\
破綻先 & 360 日以上 & 不可能 & 100 \\
\hline
\end{tabular}

出所 : チェコ中銀・銀行監督年報，各行年次報告書より筆者作成。

表5 破綻中小銀行とその主な原因

\begin{tabular}{|c|c|c|c|c|}
\hline 銀行名 & 設立時期 & 破綻時 & 主な破綻原因 & 処理策 \\
\hline Kreditni a & 1991年4月 & 1993年9月 & 縁故者向け融資 & 破産 \\
\hline \multicolumn{5}{|l|}{ průmyslová banka } \\
\hline Banka Bohemia & 1991年2月 & 1994年1月 & 債券投資失敗 & 破産 \\
\hline Česká Banka & 1992年2月 & 1995年12月 & 縁故者向け融資 & 破産 \\
\hline Ekoagrobanka & 1990年11月 & 1996年1月 & 債券投資失敗 & Union banka に売却 \\
\hline Podnikatelská Banka & 1992年12月 & 1996年1月 & 杜撰融資 & J\&T グループに売却 \\
\hline Velkomoravská banka & 1992年11月 & 1996年1月 & 引当不足 & 破産 \\
\hline AB Banka & 1991年4月 & 1996年2月 & 縁故者向け融資 & 破産 \\
\hline COOP & 1992年2月 & 1996年4月 & 信用リスク管理失敗 & Foresbankaに売却 \\
\hline Prvni sleská banka & 1993年1月 & 1996年5月 & 信用リスク管理失敗 & 破産 \\
\hline Realitnibanka & 1991年11月 & 1996年7月 & 引当不足 & 破産 \\
\hline Kreditní banka Plzeň & 1991年1月 & 1996年8月 & 縁故者向け融資 & 破産 \\
\hline Agrobanka & 1990年7月 & 1996年9月 & 債券投資失敗 & GE に売却 \\
\hline Bankovni dům Skala & 1990年12月 & 1997年3月 & - & Union banka に売却 \\
\hline Evrobanka & 1991年10月 & 1997年6月 & - & Union banka に売却 \\
\hline Pragobanka & 1990年10月 & 1998年10月 & - & 破産 \\
\hline Foresbanka & 1993年7月 & 1998年 & - & Union banka に売却 \\
\hline Universal banka & 1993年2月 & 1999年10月 & 一 & 破産 \\
\hline Moravia banka & 1992年7月 & 1999年11月 & - & 破産 \\
\hline Banka Haná & 1991年1月 & 2000年12月 & 一 & 免許剥奪 \\
\hline Union banka & 1991年11月 & 2003年1月 & 業務急扗大 ・ 縁故者向け融資 & 破産 \\
\hline Plzeřská banka & 1993年10月 & 2003年7月 & - & 破産 \\
\hline
\end{tabular}

出所 : チェコ中銀・銀行監督年報，Mejstřik（2004）等をもとに筆者作成。 
述のように社会主義時代から国有企業の在庫 - 運 転資金向けを中心に不良債権が蓄積していた。そ こでこれらを処理し，二層銀行制度下で誕生した 銀行部門が金融仲介機能を十分発揮しうる条件の 整備を目的としたものが，「第一次処理プログラ ム」(1991年)である。その概要は，大蔵省が整理 銀行を設立し，同行が国債を対価に各行から不良 倩権を買い取ってその管理, 回収にあたるもので, 回収不能時の最終損失は，国家資産基金（Fond národniho majetku)の国有企業私有化時の収入から の拠出とされた ${ }^{4)}$ 。同行は当初，125日間の時限措 置に基づく機関だったが，その後の延長を経て， 恒久機関一と発展的に改組し，大銀行で新たに発 生する不良債権を継続的に買取ることになる（表 6)。すなわち，92年には新規の不良債権 120 億コ ルナ（時価の $80 \%$ ）を購入（加えて，国家資産基 金から同行の資本増強に500億コルナ, 私有化企業 への債権放棄に380億コルナを供与) するが，その 後も CSOB, CS, KB の私有化までに, 数次の不 良債権移転（表6），引当への政府保証などが行わ れ，同行の資産も膨張していく。

他方, 中小銀行危機に対しては，二つの処理プ ログラムが策定された。その1つは，中銀のイニ シアチブによる「第二次処理プログラム」(1996 年）である。主な内容は，96年末時点での自己資 本比率 $8 \%$ 末満行に対し，その経営・資産状況か ら, 减資, 免許剥奪, 売却, 増資のいずれかの措 置を発動するもので，その際に中銀は問題行の一 部貸出債権, 保有株式を買取り, その最終損失に は政府保証が付与された。もう1つは，政府のイ ニシアチブによる「安定化プログラム」(同年)で ある。その概要は，中銀の下部機関に中小銀行の 不良債権処理機関としてチェコ金融社（Česká financní, CF）を設立し ${ }^{5)}$ ，実効的な経営改善計画 の策定等を条件に，96年末までに自己資本比率 $8 \%$ を達成可能な銀行から，銀行側に5〜 7年後の 買い戻し条件をつけて不良債権を時価で買い取る もので，6行から106億コルナ相当の資産が移転さ れた。さらに同社は上記「第二次処理プログラム」 に従い,中小各行から保有株式を含め115億コルナ 相当の資産を簿価で買い取った。なお，同社の最 終損失負担も国家資産基金からの拠出とされた (96年以降の基金の負担額は表 6 参照)。98年まで
表6 整理銀行 · 機構への不良債権移転額

（上段）および96年以降の国家資産基金 の銀行処理関連負担額（下段）

\begin{tabular}{lcl}
\hline 移転年 & $\begin{array}{c}\text { 金額 } \\
\text { (億コルナ) }\end{array}$ & 移転元銀行 \\
\hline 1991年 & 801 & (社会主義時代) \\
1992年 & 147 & KB, IB \\
1994年 & 55 & CS, IB, CS \\
& & OB, 他中小行 \\
1998年 & 265 & CS, IPB \\
1999年 & 563 & KB, CS \\
2000年 & 630 & KB, CSOB \\
2001年 & 333 & CSOB, CS, KB \\
2002年 & 852 & CSOB, CS, KB \\
\hline & & \\
\hline 1996年 & 258 & \\
1997年 & 192 & \\
1998年 & 18 & \\
1999年 & 16 & \\
2000年 & 170 & \\
2001年 & 192 & \\
2002年 & 154 & \\
2003年 & 105 & \\
\hline
\end{tabular}

注)

1）処理負担関連額は，銀行の不良債権処理の損失負担, 資本注入，整理銀行の資本増強などの合算値。

2）1997年までは Česká inkasni 分を含む。

出所：上段：Mejstřík (2004),

下段：国家資産基金年報より筆者作成。

に，2つの処理プログラムは銀行の資本增強分も 含め478億コルナ規模に至った。

2）セーフティーネットの整備・拡充

セーフティーネットの観点からは，預金保険制 度の整備が図られた。預金保険は94年に導入され るが，それ以前の破綻には中銀の裁量で払い戻し が行われていた。預金保険導入後でも，96年にか けての中小銀行危機では, 健全行も含め中小銀行 からの預金流出などが金融不安を招いたため, 預 金保険の上限10万コルナに加え, 中銀が400万コル ナまで独自に保証した。また保証対象は本来個人 のみとしていたが，これに小企業も加えたため， 預金者の99\%が保証対象となり，預金総額の66\% が支払われた（CNB，1996年版銀行監督年報）。 98年の法改正では, 払い戻し上限は30万コルナに, その後, EU 基準に合わせるかたちで，2万5千ユ 一ロ相当まで引き上げられている。 


\section{3 チェコの銀行危機とモラル・ハザード}

以上のように，90年代半ばまでに顕現化した銀 行危機に対して，国が最終損失を負担するかたち で各種処理策が講じられてきた。Tang ら世銀の試 算で，98年までに GDP 比25\%相当の処理コスト （預金払い戻しも含む）を費やし（Tang et al., 2000)，98年以降も，大銀行からの不良債権移転等 が実施されたが，結局2003年まで銀行破綻が続い た。そこで，チェコの銀行危機長期の背景を，一 連の処理策にも拘らず不良債権が減少せず，銀行 部門の脆弱性が解消しなかった点から探ることと する。その際, 外生的要因と, チェコの銀行部門 に特有な原因とに分け，特に後者について，銀行 部門に「モラル・ハザード」の典型が生じ，それ が長期化した状況を説明する。

\section{1 外生的要因}

不良債権が減少しなかった外生的要因には，次 の3 点が指摘できよう。第1にインフレ率との関係 である。チェコのインフレ率は，93年を別とすれ ば，10\%程度以下，90年代末からは 1 析と，他の 移行国と比べ低位に推移した（表1）。これは，不 良債権が実質ベースで減少しなかったことを意味 する。

第2は倒産法制の不備の問題である。例えば, 銀行が担保物件を売却しようにも市場の不備から その流動性は乏しく，不良債権を処理しにくい環 境にあった ${ }^{6)}$ 。また，裁判所での破産手続きが極 めて長期に渡るなど法制面も整備が進まず，銀行 が問題融資先を「塩漬け」にする原因にもなっ た7)。

第 3 に, 経営環境の変化である。実体経済面で は，96年末頃から景気が悪化し，97年の通貨危機 を経て景気後退が顕著になった。そこでは, 融資 先の業績悪化を通じて債権の質が劣化する。加え て，98年に銀行監督を厳格化する銀行法改正が行 われ，貸出債権の查定が強化された（Janaček, 2000）ため, 従来正常先だったものが要注意以下に 分類されて不良債権が追加されることにもなった。

\section{2 チェコの銀行部門特有の要因とモラル・八 ザード}

3.1で示したような外生的要因が，不良債権を
高い水準のままにさせたことは容易に理解しう る。しかし，10年以上に渡る危機に現れた銀行部 門の脆弱性を生んだ根本的原因の説明には不十分 であろう。すなわち, 移行期のチェコの中小銀行, 大銀行をめぐり移行期特有の「モラル・ハザード」 を助長する構造があり，これが銀行部門の脆弱性 と不良債権問題の解決を長引かせて，銀行危機を 長期化させていたと考えられる。

1) 中小銀行の問題

中小銀行の第1の問題は，1節で簡単に触れたよ うにその設立動機にあった。緩やかな設立基準の もと，設立母体や，株主，経営者に関連の深い企 業など縁故者向けの融資が相当な規模だったとさ れ（Kerous，1995），こうした融資の大半は回収見 込みがないまま実施された。これを可能とした背 景には，その設立動機ゆえ銀行内部での効果的な コントロールが効かなかったことに加え，中銀の 検查対象が当初大銀行のみだったことや，そのモ ニタリングの手法自体も未熟だったこと (Matoušek, 1998), さらには, 中銀が中小銀行の 問題を個別行のものとみなし, 解決へ向けて銀行 部門全体として取り組まなかったこと（Myant, 2003a）など, 銀行監督の点で不十分な要素も大き かった。また，経営情報開示の制度も未整備であ った ${ }^{8)}$ 。これら一連の要素は，外部コントロール の点からも不備であり，経営の脆弱性を看過する ことになった。

以下，いくつかの破綻中小銀行の事例をみてみ よう。移行開始後最初に破綻した Kreditni a průmyslová 銀行は, 頭取が約30億コルナを借入れ， これを自身と関連の深い企業に融資，結局その大 半が焦げ付いて93年 9 月に中銀の直接管理下に置 かれた。94年に破綻した Banka Bohemia の場合， 支店縲を急速に桩大（40店舗）する中，高リスク 案件の融資から経営に行き詰まる。96年1月に破 綻した Ekoagrobankaでも, 経営者関連企業向け融 資が回収不能となって破綻したが，これらは移行 初期，中銀の検查体制が不備もしくは甘い中で発 生している。

また，既に経営難にあった Agrobanka は，当初 中銀の指導に沿って経営健全化を図っていたが， 1995年に戦略的投資家として同行を事実上買収し たチェコ資本の Motoinvest 社が，中銀監督の間隙 
を縫って債券を中心に高りスク案件に傾斜し，結 局流動性危機から中銀管理下に置かれて破綻し た。

中小銀行への監督不備が端的に露呈したのは, 中小銀行の中では最大規模となっていたウニオン 銀行（Union banka）での事例である。同行は1991 年，重工業が不振に宿っていたオストラバ地方の 再生を目的に設立され，鉄鋼業の Vitkovice a Nová Hut'といった同地域の経営不振の国有企業と株式 持合いを通じて関係を強めていった。95年には金 融持ち株会社を設立し，業務を拡大していく。同 行の経営状況は，96年の銀行危機時に中銀が比較 的健全と判断しており，当局の支持むあって，銀 行危機時の破綻行を積極的に吸収合併した(表5)。 しかし，急速な業容拡大に加え，関連企業・縁故 者向け貸出の焦付きから，99年に監査法人が同行 の経営状況の不安定さを指摘するに至る。これを 受けた 2000 年の中銀の立ち入り検査では，秝故者 向け融資が全体の 3 分の 1 を占め, 正常債権は全体 の半分程度のみと判明した。中銀は同行に関する 報告書（CNB，2003）の中で，立ち入り検查まで 経営危機を見抜けなかった監督体制の不備を認め ている。同行は2003年に免許が剥奪され，2004年 現在，破産手続きが取られている。

2）大銀行部門をめぐる問題

大銀行の問題点としては，第 1 に，銀行監督の 点で，中小銀行でのケースと同様に検查体制の不 備に加え，当初検查対象が連結ベースではなかっ たため,クーポン私有化を通じた銀行の複雑な所 有関係のもとで，グループ全体の経営を適切にモ ニタリングできない状況があった。IPB の場合， 同行では既に96年頃から急激な業務拡大に伴う不 良債権の増嵩が問題となり，融資先への短期の運 転資金供与等でそれを隱蔽していたが，後に連結 ベースでの検查体制不備を突くかたちで海外にペ 一パーカンパニーを設立し，不良債権の移転工作 を図っていた（Kudrna et al., 2002）。

第2に，コニバーサル・バンキングの採用によ る問題である。ドイツをモデルに，私有化される 銀行と企業との間の長期的関係構築を通じた企業 統治の実現を目指寸ものであったが（Desaj, 1996), チェコではクーポン私有化と投資基金設立 を通じて銀行が企業の大株主となっており，
Hrnciŕr（1993）の懸念どおり，貸し手としての役 割との間で「利益相反関倸」が生じて，銀行自ら の業績を犠牲にして経営不振の融資先を簡単には 破産させられない状況になっていた。IPB では, 産業部門の再結合を目的に，移行期に国営大企業 から分割され旧来の連関が崩れて困難に直面して いた企業の株式を，侳下の投資基金を通じて積極 的に買い入れたが，こうした行動は結果的に同行 グルーブ内部で梁刻な利益相反をもたらした (Kudrna et al., 2002; Myant, 2003a)。

第3は，大銀行の私有化の遅れである（Bures， 2001；Sojka，2003）。クーポン私有化後も IPB を 例外として，90年代末まで大銀行の株式は国家資 産基金ほか政府部門が約半分もしくは過半を保有 しており，政府が銀行経営に影響力を行使できる 状況にあった（表 3 )。銀行私有化が遅れた背景の 一つには，チェコ財政が移行初期はみかけ上健全 であり（表 1），政府に銀行株を売却する動機がそ しかったことも考えられる。しかしより本質的な 理由には，大銀行への影響力を残し，戦略的な融 資を支援することで，市場経済化にともなう改革 の痛みを和らげる狙いがあったと考えられる。特 に，大銀行が私有化されて経営効率のみを図り， 経営難の（旧）国有企業向けといった問題先の融 資を打ち切った場合には，大量失業等の深刻な影 響が想起された。当時与党の市民民主党（ODS） 関倸者のなかでは，政府の大銀行株保有こそ銀行 部門の信認を維持する，といった認識や，私有化 で外資が参入すると，収益第一主義から制限的な 貸出が行われる，といった眯念もあった(この点， 表 7 のうに，ハンガリーは積極的に，またポー ランドでも多少の懸念を表明しつつも，外資を排 除せずにチェコよりも早期に大銀行を私有化した 点は顕著に異なる)。KBでみると，同行は社会主 義時代からのメインバンクとして，大口貸出先に シュコダ社やタトラ社といった経営不振の国有企 業を多く抱えていた。91〜92年の整理銀行への不 良債権移転後も，政府は KBに（旧）国営企業向 けに新規融資を行わせ，それらの貸出残高に占め る比率は，91年に $8 \% ， 92$ 年には $23 \%$ に上，ま た総資産の約 $60 \%$ は従来からの取引のある大・中 規模の（旧）国営企業向け貸出で占められていた (Kormendi et al., 1997) 9)。加えて KB は，雇用吸 
表7 ハンガリー, ポーランドの銀行私有化

\begin{tabular}{lll}
\hline ハンカJリー & 銀行名 & 主要株主 \\
\hline 1994年 & 外国貿易銀行 & (独)Bayerische \\
& & \multicolumn{1}{c}{ Landesbank } \\
1995年 & ブダペスト銀行 & (米)GE \\
1996年 & ハンガリー信用銀行 & (蘭)ABN-AMRO \\
1996年 & 総合銀行 & (露) ガスプロム銀行 \\
1995-97年 & OTP 銀行 & (国内) \\
1997年 & K\&H 銀行 & (白)Kreditbank \\
1997年 & 農業銀行 & (墺)Girocredit \\
1997年 & 貯蓄共同銀行 & (独)Deutsche \\
& & Genossenschaft \\
1997年 & PK 銀行 & (国内) Atlasz \\
\hline ポーランド & 銀行名 & 主要株主 \\
\hline 1995年 & WBK & (愛)アイルランド \\
& & 連合銀行 \\
1996年 & Bank Slaski & (闌)ING \\
1995年 & BPH & (独)Bayerische \\
& & Hypo-Vereinsbank \\
1995年 & Bank Gdanski & (独)Deutsche Bank \\
1997年 & Bank Handlowi & (米)JP Morgan 他 \\
1997年 & PBK & (国内) \\
\hline 1998年 & PeKao & (伊)Unicredito \\
\hline
\end{tabular}

出所 : ハンガリー : Green et al. (2002) より筆者作成, ポーランド: Bonin（1999）より筆者作成。

収先として新興企業を支援する政府の要請もあっ て，それらに積極的に融資したが，甘い審查も手 伝ってこれらが不良債権化する（Myant，2003a）。 国内預金最大の吸収先である CS も，中小銀行危 機で貸出先の転換を迫られる中, 経営困難にあっ た化学産業等（旧）国有企業を積極的に買収して いた Chemapol グループに傾斜，（政府部門の保有 比率は低下していたが) IPB も Chemapol や不振の 車輛メーカーČKD 社など旧国営企業向けに積極 的であった（ibid）。他方，借り手の側として，経 営困難下のシュコダ社をみると，政府の支援もあ って，経営陣が起死回生を図るべく新製品への積 極投資を行い，93年～97年に業績は8億コルナの 黒字から38億コルナの赤字へと悪化する一方，銀 行借入は40億コルナから130億コルナへと急拡大 しており゙ (ibid)，この間の銀行の融資姿勢が表わ れている。このようにみると, チェコの大銀行に は，移行期のショック緩和の上で「重要すぎて私 有化できない」もしくは，不良債権を多く抱えて いてもその影響の大きさゆえ「大きすぎて潰せな い状況が生じていた。そこでは, 銀行経営陣に
銀行が倒産させられることはないとの「暗黙の政 府保証」(後述) の認識を与え, 経営改善のインセ ンティブが削がれた可能性が考えられる。

第 4 の問題は，不良債権移転等の「救済スキー ム」である。移行開始直後から，整理銀行および その後身の整理機構に，度重なる不良債権の移転 （表6）や，国家資産基金加らの大銀行人の資本注 入が行われている。これらは明確な基準に従って 実施されたというよりも，不良債権増嵩と銀行危 機一の眯念からアドホックに行われた側面が大き い。同時に，これら一連のスキーム実施とその後 の最終損失に対寸る「安易な」財源にも問題があ った。政府保証を通じた銀行処理の損失は，不良 債権移転時点では顕現化しない「隠れ債務」であ り，加えて，整理銀行，同行に資金提供する国家 資産基金，そして銀行処理時の最終損失一の政府 保証は，いずれも一般政府勘定外に置かれ，銀行 処理コストは議会審議プロセスに明確には反映さ れないものであった。すなわち，度重なる銀行処 理・救済には，国家資産基金等が「打ち出の小槌」 となって安易なファイナンスを可能にしていた。 さらにその「隱れ債務」化は，見かけ上チェコ財 政が健全との印象を与える副作用をも招いた。

3）小括:「モラル・ハザード」からみたチェコの

銀行部門

以上, チェコの銀行部門特有の状況を述べたが, 既に一部示唆したように,チェコの銀行部門に「モ ラル・ハザード」を発生させ，それゆえ危機が長 期化した可能性が高い。以下では，酒井・前田 (2004), 古川 (2002), Dewatripont and Tirole (1994) 等のテキストを手掛かりとして，銀行部門をめぐ る「モラル・八ザード」を, 銀行, 預金者, 借り 手，中銀・政策当局それぞれの経済主体の観点か ら整理し，チェコでの状況を確認する。図1では 上記 $4 つ の$ 主体の行動とモラル・ハザード発生の 関係を概念的に示したものである。矢印の向きは, 矢印の起点となっている主体の, 矢印で指されて いる主体への行動がモラル・ハザードを生じさせ ることを表している（図中矢印の横の数字は下記 (1) (4)に対応)。

(1)は，「金融機関が経営リスクを過大にとる行 動」としてのモラル・ハザードで，預金者を犠牲 にして，銀行が過大なリスクのある案件をとる， 
もしくは銀行経営に銀行資産を安易に管理するイ ンセンティブがある状海を指し，これは預金保険 ないし破綻銀行を政府が救済するという「暗黙の 保証」がある場合に生じる。この場合，投資家の 銀行経営者のモニタリング，もしくは預金者を投 資家とみなせば，預金者のモニター代表としての 「銀行規制（監督）機関」が，金融機関を監視，検 査することでモラル・ハザード発生の防止が期待 される (Dewatripont and Tirole, 1994; 古川, 2002)。

(2)他方，預金者の側には「セーフティーネット 拡充に伴うモラル・ハザード」発生の余地がある。 預金保険制度等のセーフティーネットの拡充は, 預金者に金融機関の経営内容を無関心にさせ，金 融機関など市場参加者の行動をチェックする「市 場規律」の働きを阻害し，リスクテイキングを促 進させて，導入の意図とは逆にセーフティーネッ トが金融システム全体を弱体化させる可能性が生 じる。

(3)借り手の側では，「貸出市場におけるモラル・ 八ザード」というべき状況がある。これは，借り 手 (企業)・貸し手（銀行）間に「情報の非対称性」 が存在する（投資収益の成果・リスクが企業には 分かるが，投資家には分からない）悔に借り手企 業がハイリスク・ハイリターンの投資を行うよう な，前者が後者を犠牲に自らの利益を高める行動 を取る場合に発生する。

(4)は銀行救済にかかるモラル・八ザードを示し ている。(1)，(2)で生じるようなモラル・八ザード の防止のためには, 経営危機行への当局の措置発 動（中銀の最後の貸し手機能など）に際して, 経 営責任が明確化（経営陣の退陣, 株主・出資者の 資本金・出資金の損失などへの充当など）されて いることが原則であり（日本銀行，2003），救済の 繰り返しはモラル・ハザードを助長 (Hrnciír, 1993;

Matoušek，1998）する結果となる。

以上の整理から，チェコでの状況をモラル・八 ザードに即して検討すると，(1)関しては，前述 の KB の事例に加えて, CS の不良債権急増の背景 も説明できよう。CS は先述したリスクの高い Chemapol 社向けに加えロシア国債にも傾倒し，98 年には前者で110億コルナの焦げ付きが, 後者では ロシア危機で55億コルナの損失を生じたが，（旧） 国営企業との結びつきの強いKB および国内貯蓄
図1 モラル・ハザードの概念図

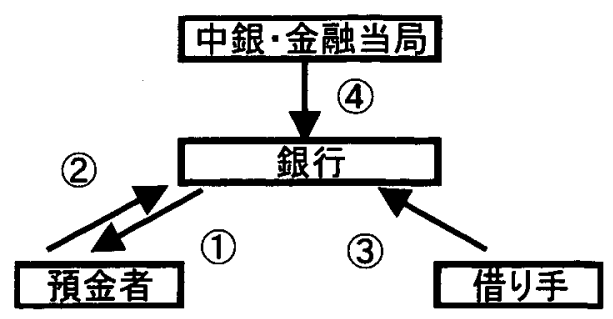

出所 : 筆者作成。

の最大吸収先でもある CS は，大きすぎて潰せな いか，重要すぎて私有化できないものとなり，「暗 黙の政府保証」が生じていた（後述(4)の観点から は, 各行の度重なる救済で既に「明示された」政 隹保証だったともいえる。IPB についても，その （旧）国有企業との関倸強化は, 政府とその関係者 からの肯定的評価によって「保証」を意味した, とも理解できる)。経営へのモニタリングでは, 中 小銀行危機までは中銀の側に検查能力もしくは経 営介入権限が小さかった点, また大銀行について は連結ベースでの検査が行えなかった点から，モ ラル・ハザードを助長させたといえよう。

(2)のセーフティーネット拡充については, 預金 保険が段階的に，時には中銀の裁量で拡充された ことをみた。この点, 経営危機が表面化していた IPB で，外資（野村系）の資本参加とも相俟った ものであるが，98年には預金量を前年比30\%超も 増加させている（表8）ことは興味深い。

(3については，市場経済化の初期の銀行が，貸 し手へのリスク管理能力が不十分である一方, 新 興企業等の借り手との間で，企業情報について非 対称性が顕著だったことは明らかである。また， 政府の支援にも拠るものだが,シュコダ社での(成 果の不透明な）積極投資と借入れ増大が不良債権 化したケースも，これに該当しよう。

さらに，(4)の銀行救済の点では，基準が曖昧な まま, 大銀行を中心に度重なる不良債権の切り離 しや救済策が害行され，かつ整理銀行とその資金 源である国家資産基金を通じて，安易なファイナ ンスが可能な仕組みが出来ていたことが，モラ ル・ハザードを助長したことは明らかである。1999 年, 経営危機下の CS の壳却先選定に際し，翌年 


\section{表8 預金増加率の推移}

\begin{tabular}{lrrrrrrrrrr}
\hline & 94 年 & 95 年 & 96 年 & 97 年 & 98 年 & 99 年 & 2000 年 & 01 年 & 02 年 & 03 年 \\
\hline 銀行部門全体 & 18.7 & 14.7 & 6.1 & 13.9 & 4.7 & 9.1 & 7.2 & 7.5 & 7.5 & 2.3 \\
うち KB & 13.8 & 15.1 & 18.0 & 5.9 & -7.8 & -5.3 & 11.0 & 0.7 & 5.6 & 3.3 \\
CS & 4.4 & -2.0 & 0.0 & 2.0 & -1.0 & -0.6 & 8.8 & 9.9 & 1.0 & 2.7 \\
IPB & 37.4 & 38.2 & 23.0 & 18.1 & 31.3 & n/a & - & - & - & - \\
\hline
\end{tabular}

注) 年末值対前年比。

出所：チェコ中央銀行公表データ，各行年次報告書より筆者作成。

には破綻に至るIPB が買収に名乗り出た (Juchelka，2001）ことは，チェコの銀行部門で救 済の繰り返しが当てにされていたことを正に象徵 している。

\section{結びーチェコの銀行部門の脆弱性，モラル ハザードは解決したのか?}

以上, チェコの銀行危機の長期化について，銀 行部門をめぐる特有の環境から，モラル・八ザー ドにその原因を求めた。国家資産基金，政府保証 を財源とする安易な銀行救済に加え，銀行私有化 の遅れも相俟って，銀行危機は長期化し，銀行・ 企業間の「ソフトな予算制約」が継続する結果に もなった。もっともこのような構造は，例えば Desaj（1995）が中小銀行危機ピーク前に明らかに していた。従って，なぜ長期に渡るモラル・八ザ 一ドが生じる状況を政府が改善させなかったかと

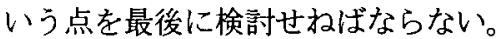

投資基金を通じた大銀行間の持合い構造の成立 は，移行当初政府が意図したものではなかった (Desaj, 1996)。しかし，銀行の孫会社（文末注2参 照）を用いる脱法寸前の行動が当局に追諗される のは，厳格な融資姿勢を求めるような部門外のコ ントロールに銀行が服する事態を防ぐ (Rao et al., 2003）ツールになったためであった。同様に大銀 行の私有化を遅らせたことで，(旧）国営企業のソ フトな予算制約も維持され，移行のショックは緩 和された。他の移行諸国と比べ，チェコの移行期 の失業率が低位に推移した（表 1）のは，そうし た状況の裹返しである。すなわち，クラウスは, チェコの目指す市場経済は「いかなる形容詞もつ かない (Machonin et al., 2000) ものとして, 極 めて自由主義的なレトリックを提示し，それはク 一ポン方式による急速な私有化に象徴されたが,
実際の移行戦略では，政府部門の大銀行の株式保 有，整理銀行・国家資産基金といった体制移行機 関（transformační instituce）の無尽蔵に近い資金供 給，破産関連の法制度整備の停滞 ${ }^{10)}$ 等が「道具」 となって，チェコ経済の抜本的改革は先送りされ ていたのである。紙幅の都合上その仔細な検討は 別稿に譲らざるを得ないが，このような 90 年代半 ばの経済構造は，チェコでは「銀行社会主義 (bankovní socialismus)」とも評された（Havel, 2001：Sojka，2003）。銀行部門をめぐるモラル・ 八ザードが助長される構造が存置された背景は, こうしたチェコの移行戦略の文脈において理解さ れよう。

それでは現在, チェコの銀行部門の脆弱性は解 決し，モラル・八ザードの助長を防げる状況にあ るのだろうか。その検討に入る際，チェコでの政 権交替からみていきたい。97年の通貨危機を経て 実体経済も悪化したチェコでは，折しも政権与党 ODS での政治資金スキャンダルが発生し，チェコ の市場経済移行を担ってきたクラウスは退陣，そ の移行路線は挫折した（池本・松澤，2004）。暫定 内閣を経て98年に社会民主党政権に交替するが， 以降経済政策は大きく変化した。とりわけクラウ スの「欧州懐疑」の姿勢もあって慎重だった EU 加盟への動き（98年に加盟交涉開始）が，政策転 換の大きな契機ともなった。

銀行法は98年から改正され，銀行監督・規制の 面で大幅な強化，改善をみた。銀行規制では，銀 行の内部コントロール欠如が危機を招来したとの 反省から，(1)銀行の非金融機関に対する多数株支 配の禁止，(2)銀行職員の兼業禁止，(3)貸出部門上 投資部門の明確な分離を図った。また，銀行監督 では，中銀の介入権限を強化 (所要自己資本が 3 分 の2を下回った銀行への免許取消権限等) し, 2000 
年には連結ベースでの検查を開始，2001年からは 銀行と関連企業の所有構造の開示拡充が行われ た。これら一連の措置は, EU の銀行規制・監督 への調和を図ったものでもある。

他方，従来の不良債権処理・銀行救済の仕組み については，98年に政府内部でもモラル・八ザー ド助長の危険性に関する報告書が作成され，問題 認識に至っていた（World Bank, 2000b）が，欧州 委員会他国際機関からの強い要請で，02年から整 理機構（整理銀行から改組）が一般政府の繰り入 れられ，政府保証についても2001年に保証額の上 限を歳入の $40 \%$ 以下とし，04年からその財政支出 見通しが予算に，同残高が一般政府勘定にそれぞ れ計上されて，「打出の小槌」であった機関の運営 の透明性が向上した。従って, EU 加盟という圧 力（Sojka，2003）も梃子となって, 制度面からは これまでのようなモラル・ハザードを生じるよう な状況から脱却しているように思われる。

また銀行部門では，一連の破綻処理を通じ，移 行初期に設立された経営基盤の弱い中小銀行は 「退場」した。大銀行については，その危機的状況 を認識した社民党政権下で私有化が推進され，99 年から2001年にかけて, CSOB，CS，KB の各行 がそれぞれ，ベルギー系 $\mathrm{KBC}$ グループ，オース トリア系 Erste グループ, フランス系ソシエテ・ ジェネラルグループに売却されて私有化は完了し た。その結果，03年末時点で外国系が銀行部門の 総資産中 $97 \%$ を支配するかたちとなった。他方， 中銀試算で850億コルナのコストをかけた大銀行 私有化時の不良債権処理もあって，銀行部門の不 良債権比率は $10 \%$ 近傍まで減少した。また，金融 仲介機能の回復の点では, 信用乗数は足許下げ止

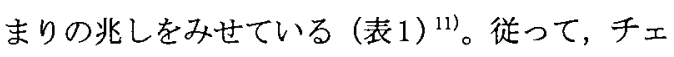
コの銀行部門の脆弱性はようやく解消されつつあ る姿を示している ${ }^{12) 。 ~}$

ただし，整理機構の損失処理を織り込んだ財政 赤字対 GDP 比（表 1）は，2003年速報值で5.1\% と, 通貨統合の収斂基準加ら大幅に乘離し, 財政 改革実現をも前提とした楽観的な政府見通し (2004年試算) でも，07年時点で同 $3.5 \%$ となって いる。従って, チェコの銀行部門は脆弱性克服一 向けた「正常化」への道を歩む一方，クラウス流 移行戦略によって現出した擬似「金融資本主義」
の下で生み出された不良債権という負の遺産の処 理に，依然として課題を残しているのが現状であ る。

(桜美林大学経済学部非常勤講師 一橋大学大学院経済学研究科博士後期課程)

注

*) 本稿は, 比較経済体制学会第 3 回秋期研究報告 会 (於中央大学) での報告を加䈉・修正したものである。 本稿執筆に際しては，西村可明教授（一橋大学経済研究 所), 岩崎一郎助教授 (同), 杉浦史和講師（同）および 本誌匿名論文審查員の各位ほか力加有益なコメントを, また Jan Klacek 博士（元チェコ中銀経済研究所所長）, Peter Havlik 博士（ウィーン国際経済研究所）には資料収 集に当たってご助力を頂いた。記して謝意を表したい。 また，現地調查，資料収集には，2004年度 EU Institute in Japan（EUIJ） スカラシップを利用した。

1）個人対象の外為専門銀行ジブノステンスカー銀行 (Živnostenská banka，ZB，小銀行に分類）も普通銀行に 転換された。なお，チェコ各行の前史および移行開始後 の詳しい展開は Vecovský et al. (1999) および Revenda (2001) 参照。

2）銀行設立の投資基金は親会社および金融機関の株 式保有を禁じられていたにもかかわらず，法の間隙を縫 って, 銀行は孫会社を通じて金融機関相互の持合い構造 を形成させていく。その背景には，(1)銀行株をその将来 性の期待から積極的にポートフォリオに組み入れるイ ンセンティブがあったことに加え，(2)設立母体行が銀行 外部のコントロールに服することを嫌った点が指摘さ れている（Rao et al. 2003）。

3）この間，CSOB では深刻な経営危機には至らず, Myant（2004）は中銀の株式保有比率の高さが好ましく 影響したとしている。

4）その他, CSOBの対コメコン諸国等の不良債権処 理機関として, Ceska inkasní(CI) が設立された。

5) 同社は2001年に整理銀行の後身「整理機構(Česká konsolidační agentura)」に吸収された。

6）そのような事情もあり，98年以降不動産担保には 100\%の引当が課されている。

7）欧州委員会は EU 加盟交涉に際して，定期報告書 (Regular Report) の中で市場参入・退出に関する事項で の不備を継続的に指摘し, 特に企業のリストラ, 再生を 停滞させているとして, 裁判所をはじめ破産処理能力の 向上や制度改善を求めた。

8）チェコ中銀でも，銀行監督年報で銀行部門の要注 意区分以下の分類債権比率を公表したのは1996年版か らである。

9）まだ政府の株式保有比率の高かった 90 年代半ばの IPBは，旧国有企業向けにも積極的に融資しており，当 時の国家資産基金総裁は「最も柔軟な銀行」と評伍して いた (Myant, 2003b)。 
10）Mejstrúk (1999) は, 政府が（敢えて）破産プロ セスのスピードを停滞させていた旨の評価している。

11）ただし，銀行貸出は依然停滞しており（表 1), その間，銀行はリスク回避から資産に国債を積み上げて いる。

12）ウィーン国際経済研究所 Havlik 副所長は，2004 年筆者とのインタビューで, 2003年の 2 銀行のケースは 銀行部門安定確立人向けた最後の処理との評価をして いる。

\section{参考文献}

池本修一・松澤祐介（2004）「チェコの体制転換プロセ ス一擬似『金融資本主義』の破綻と『正常化』 向けての模索」『ロシア研究』36, pp. 111-142, 日本国際問題研究所.

岡部光明 (1999)『環境変化と日本の金融』日本評論社.

酒井良清・前田康男 (2004)『金融システムの経済学』 東洋経済新報社

日本銀行 (2003)『日銀特融等実施のための「4 原則」』. 古川顕 (2002)『現代の金融 (第二版)』東洋経済新報社.

渡辺孝（2001）『不良債権はなぜ消えないのか』日経 B $P$ 社.

Bonin, John and Paul Wachtel (1999) "Lessons from Bank Privatization in Central Europe", presented at the Bank Privatization Policy Research Workshop, Washington, D.C.

Bures, Oldrich (2001) "Czech Banking Reform-Biggest Free Lunch Ever?", 10th International Anti Corruption Conference.

Česká narodní banka (CNB) Bankovni dohled（銀行監督年 報）各号.

(1999) Report on Banking Supervision in the Czech Republic.

- (2000a) Transformančni naklady na ozdraveni a konsolidaci bankovního sektoru-Podklad pro Rozpoctovy vybol.

- (2000b) Zpróva pro jednáni Poslanecké sněmovny Parlamentu České republiky o vívoji situace a postupu řešeni stabilizace Investični a Poštovni banky, a.s.

(2003) Informace pro jednání Poslanecké snèmovny Parlamentu České republiky $k$ vývoji situace Union banky, a. s. zveřejnèna.

Desai, M. Raj (1995) "Financial Market Reform in the Czech Republic, 1991-1994: The Revival of Repression?", CERGE - EI Working Paper, no.86.

(1996) "Reformed banks and Corporate Governance in the Czech Republic, 1991-1996", Postsoviet Geography and Economics, Vol.37, No.8, pp. $463-494$.

Dewatripont, Mathias and Jean Tirole (1994) The Prudential Regulation of Banks, The MIT Press（北村行伸/渡 辺努訳（1996）『銀行規制の新潮流』東洋経済新
報社).

European Commission Regular Report from the Commission on the Czech Republic, Various issues.

Green, David. eds. (2002) Banking and Financial Stability in Central Europe, Cheltenham, UK: Edward Elgar.

Hajkova, Dana., Hanousek Jan and Liber Nemecek (2002) "The Czech Republic's Banking Sector: Emerging from Turbulent Times", EIB Papers, 2002/1, pp5572.

Havel, Jiři (2001) "Bank Privatisation, Critical Look at Privatisation Procedures", paper for Future of The Banking After the Year 2000 in the World and in the Czech Republic VI: Privatization of the Banking Sector, 17 -18 October 2001, Karviná.

Hrncî́, Miroslav (1993) "Financial Intermediation in Former Czechoslovakia and in the Czech Republic: Lesson and Progress Evaluation", Economic Systems, Vol.17, No.4, pp301-327.

International Monetary Fund Staff Country Report: Czech Republic, Washington D.C., Various issues.

Janaček, Kamil (2000) "Macroeconomic Implications of the Regulatory Policy of the Czech National Bank", Komerčni banka Economic Trends, No. 20.

Janácek, Kamil and Vladimir Tomšik (2000) "Development of the Banking and Financial Institutions in the Czech Republic", Komerčni banka Economic Trends, No.26.

Jonaš, Jiři (1998) Bankovni krize a ekonomická transformace, Praha: Management Press.

Juchelka, Jan (2001) "The National Property Fund View on the Banking Sector Privatization", paper for Future of The Banking After the Year 2000 in the World and in the Czech Republic VI: Privatization of the Banking Sector, 17-18 October 2001, Karviná.

Kerous, Miroslav (1995) "Key Issues in Czech and Slovak Banking", in Stephany Griffs - Jones and Zdanek Drabek eds., Financial Reform in the Transition to a Market Economy, New York, USA: Palgrave Macmillan.

Kormendi, Roger C. and Edward A. Synyder (1997) "The Czech Republic's Commercial Bank: Komerční Banka", Journal of Comparative Economics, Vol.25, pp. $97-128$.

Kudma, Zdeněk et al. (2002) Vzestup a pad Investični $a$ poštovni banky, Praha: Univerzita Karlova.

Machonin, Pavel, Mlčoch, Lubomír and Milan Sojka (2000) Economic and Social Change in Czech Society After 1989. An Alternative View, Prague: Karolinum.

Matoušek, Roman (1998) "The Czech Banking System in the Light of Regulation and Supervision: Selected Issues", Czech National Bank Working Paper, No.5

Matoušek, Roman and Anita Taci (2000) "The Assessment of the Cost and Benefit of the Small and Medium Commercial Bank within the Czech Banking Sector", in Hölsher. J. eds., Financial Turbulences and Capital 
Markets in Transition Economies, Houndsmil, Macmillan.

Mejstřik, Michal (1999) "The Restructuring after Privatization in the Czech Republic", Prague Economic Papers, Vol.8, No.3, pp233-260.

- (2001) "Czech Financial Sector Development and Problems of Corporate Governance" in Restructuring and Development of the Banking Sector in Advanced Transition Countries: Lessons to be Learnt by Other Transition Economies, Economic Policy Institute Sofia Discussion Papers, 8.

- (2004) Czech Republic: Completing the Transformation of Banks and Enterprises, Prague: Karolinum Press.

Mlčoch. Lubomír (1997) "Czech Privatization-Penalties for the Speed", Prague Economic Papers, Vol. 6, No. 1, pp. $3-14$.

Myant, Martin (2003a) The Rise and Fall of Czech Capitalism, Cheltenham, UK: Edward Elger.

(2003b) "Czech Banking in Comparative Perspective", Prague Economic Papers, Vol.12, no.2, pp. 131 $-144$.

(2004) "Czech Capitalism - Towards a European Model?", Paper for Managing the Economic Transition, 13th Research Seminar, Cambridge University.

OECD Economic Surveys: Czech Republic, Paris, Various issues.

Revenda, Zbyněk (2001) Centrálni bankovnictvy, Praha:
Management Press.

Pavlínek, Petr (2003) "Alternative Theoretical Approaches to Post - Communist Transformations in Central and Eastern Europe", ACTA SLAVICA IAPONICA, Vol.20, pp. $85-108$.

Polouček, Stanislav eds. (2004) Reforming the Financial Sector in Central European Countries, New York, USA: Palgrave Macmillan.

Rao, Hayagreeva and Paul Hirsch (2003) "Czechmate: The Old Banking Elite and the Construction of Investment Privatization Funds in the Czech Republic", SocioEconomic Review, Vol.1, No.2, pp. 247-269.

Schütte, Clemens (2000) Privatization and Corporate Control in the Czech Republic, Cheltenham, UK: Edward Elger.

Sojka, Milan (2003) "Czech Transformation Strategy and Its Economic Consequences: A Case of an Institutional Failure", in Democracy and Market Economics in Central and Eastern Europe: Are New Institutions Being Consolidated? , Slavic Research Center.

Tang, Helena, Edda, Zoli and Irina Klytchnikova (2000) "Banking Crises in Transition Economies", World Bank Policy Research Working Paper, 2484.

Vecovský, František, Jindra, Zdaněk, Novotoný, Jiři, Půlpan, Karel, Dovoráa, Petr (1999) Déjiny Bankovnictvi v Ceských Zemich, Praha: Bankovni institut.

World Bank (1999) Czech Republic: Toward EU Accession, Washington D.C. 


\section{Abstracts}

What Difficulties Has Serbia and Montenegro Faced in the Process of EU Accession and Economic Transition?

Nozomu Abe (Faculty of International Studies, Meiji Gakuin University)

South-East Europe, which is expected to join the EU in the future, has not passed the entrance examination of the EU yet due to various kinds of hurdles. This article examines the process of economic transition and EU accession of Serbia and Montenegro, which is one of the most lagging-behind runners in an EU accession race. It concludes that the standardised international assistance packages to Serbia and Montenegro are much less effective due to the complexity of its state structure and that a settlement of Kosovo Issue will be the far most important precondition for its successful transition.

\section{Special Economic Zones in Poland: Evaluation} of Foreign Direct Investment Promotion Policy Hiroshi Kaneko (Graduate School of Economics, Hitotsubashi University, Ph. D student)

In the early years of the Polish economic transition, the fast growing economic performance gap between the regions emerged as a serious socio-economic issue. Regions holding heavy industrial areas, rural agricultural areas and R\&D centres were hit hardest and unemployment as well as great decline of outputs reached a formidable level. The Polish government established Special Economic Zones (SEZs) in such regions, introducing investment incentives to attract foreign investors. Though major multinational enter- prises often choose SEZs as their plant locations in Poland, only a small portion of FDI has been realized in SEZs and the amount of employment generated in SEZs is far from its original target number. The conclusion of this paper is that SEZs as an FDI promotion policy instrument brought a certain level of success but not as much as the Polish government expected.

\section{The Problem of Non-payment and Banking} Sector Development in Russia

Fumikazu Sugiura (Institute of Economic Research, Hitotsubashi University)

During its transition to a market-based economy, Russia has experienced a severe non-payment problem. We analyze the emergence and development of arrears problem in the banking sector, putting a special emphasis upon the interrelation between the ratio of the non-performing loan and the quantitative and qualitative characteristics of each bank. We find that the banks with the origin of the former specialized banks tend to have a higher ratio of the non-performing loan, while the newly established private banks have a lower one. This shows that the banking sector in Russia has been quite segmented.

\section{Banking Crisis in the Czech Republic during the Transition}

Yuusuke Matsuzawa (Graduate School of Economics, Hitotsubashi University, Ph. D student)

The banking crisis in the Czech Republic continued for almost a decade during the transition because "moral hazard" was embedded in the 
banking sector, reflecting underdeveloped banking regulations and supervision, delayed privatization, ad hoc rescue programs, and financial injections for collapsed banks by quasi-state money as easy financial tools that mitigated the transition shocks. The situation improved due to the completion of privatization of banks and modification of banking regulations to meet the EU standard. However, the fiscal burden of clearing up the huge non-performing loans that are transferred from banks to the state agencies is still a large issue.
The Role of the State in Economic Transition and Growth: A Survey

Taku Suzuki (Graduate School of Economics, Hitotsubashi University, Ph. D. student)

The purpose of this paper is to survey arguments about the role of government in transition and to put them in order from the viewpoint of economic growth. The remark can be summarized to three points below. 1) While the governments of transition countries need to advance many policies, the room for a further examination about the speed of marketization is suggested by some persons. 2) The thoroughness in rule of law and prevention of corruption are requested to reserve their capability of policy execution. 3) The possibility that the democratization assures continuous growth is suggested by many papers. 